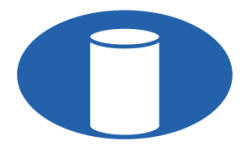

IBRACON Structures and Materials Journal

Revista IBRACON de Estruturas e Materiais

IBRACON

ISSN 1983-4195

ismj.org

ORIGINAL ARTICLE

\title{
Seismic reliability assessment of a non-seismic reinforced concrete framed structure designed according to ABNT NBR 6118:2014
}

\section{Avaliação da confiabilidade sísmica de um pórtico de concreto armado não sismo-resistente dimensionado de acordo com a ABNT NBR 6118:2014}

\author{
Eduardo Marques Vieira Pereira ${ }^{\mathrm{a}}$ \\ Gustavo Henrique Ferreira Cavalcante ${ }^{\mathrm{a}}$ (D) \\ Isabela Durci Rodrigues ${ }^{\mathrm{b}}$ \\ Luiz Carlos Marcos Vieira Júnior ${ }^{\mathrm{a}}$ \\ Gustavo Henrique Siqueira ${ }^{a}$
}

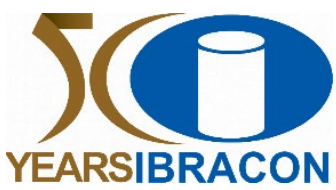

\footnotetext{
a'Universidade Estadual de Campinas - UNICAMP, Faculdade de Engenharia Civil, Arquitetura e Urbanismo, Departamento de Estruturas, Campinas, SP, Brasil

bUniversidade de São Paulo - USP, Escola de Engenharia de São Carlos, Departamento de Estruturas, São Carlos, SP, Brasil
}

Received 18 March 2021

Accepted 26 June 2021

\begin{abstract}
Due to the paucity of studies regarding the seismic assessment of buildings in Brazil, this study aims to present and discuss a seismic reliability assessment of a reinforced concrete framed structure designed according to the Brazilian standard ABNT NBR 6118:2014 without the consideration of the seismic design requirements of ABNT NBR 15421:2006. Herein, fragility functions are generated through probabilistic seismic demand analysis, and integrated with hazard curves for Northeastern Brazil to generate regional failure probability maps for three limit-states: Immediate Occupancy (IO), Life Safety (LS), and Collapse Prevention (CP). The results indicated that the building performance is adequate for IO; however, for $\mathrm{LS}$ and $\mathrm{CP}$, an unacceptable performance is observed.
\end{abstract}

Keywords: reinforced concrete, earthquakes, fragility functions, reliability.

Resumo: Diante da escassez de estudos sobre a avaliação sísmica de edificações brasileiras, esse estudo tem como objetivo apresentar e discutir a avaliação da confiabilidade sísmica de um pórtico de concreto armado dimensionado de acordo com a ABNT NBR 6118:2014 sem a consideração do dimensionamento sísmico prescrito pela ABNT NBR 15421:2006. Neste trabalho, funções de fragilidade são geradas através de análises probabilísticas de demanda sísmica e integradas com curvas de ameaça sísmica da região Nordeste do Brasil para gerar mapas regionais de probabilidade de falha para três estados limites: Ocupação Imediata (IO), Segurança à Vida (LS) e Prevenção ao Colapso (CP). Os resultados indicam que o desempenho da edificação é adequado para IO, mas para LS e CP, um desempenho inaceitável é observado.

Palavras-chave: concreto armado, sismos, funções de fragilidade, confiabilidade.

How to cite: E. M. V. Pereira, G. H. F. Cavalcante, I. D. Rodrigues, L. C. M. Vieira Júnior, and G. H. Siqueira, "Seismic reliability assessment of a non-seismic reinforced concrete framed structure designed according to ABNT NBR 6118:2014," Rev. IBRACON Estrut. Mater., vol. 15, no. 1, e15110, 2022, https://doi.org/10.1590/S1983-41952022000100010

Corresponding author: Eduardo Marques Vieira Pereira. E-mail: eduardo.marquesvp@gmail.com

Financial support: Coordenação de Aperfeiçoamento de Pessoal de Nível Superior - Brasil (CAPES) - Finance Code 001; São Paulo Research Foundation (FAPESP) -

Finance Code 2018/23304-9.

Conflict of interest: Nothing to declare. 


\section{INTRODUCTION}

Brazil is located in a stable mid-plate South America region. The country, however, presents a considerable history of small-to-moderate earthquakes (Berrocal et al. [1], Assumpção et al. [2]). According to [2], in Brazil, moment magnitude (M) 5.0 events occur on average every five years, whereas M6.0 events are expected on average every 50 years. Since seismic risk is a combination of seismic hazard, exposure and structures' vulnerability, and although strong earthquakes are not expected or less frequent, if buildings are not properly detailed and designed to withstand seismic loads, high losses due to small-to-moderate events may be expected. For instance, Nievas et al. [3] present an extensive database of events worldwide with $\mathrm{M}$ from 4.0 to 5.5 for which damage and/or casualties have been reported. It also has to be highlighted damaging events that have occurred in Brazil, e.g., the João Câmara earthquake in Rio Grande do Norte state and the Itacarambi earthquake in Minas Gerais state ([2], Takeya et al. [4]); the latter causing the first reported fatal victim due to earthquakes in Brazil.

However, the first earthquake-resistant structural design code for buildings in Brazil, ABNT NBR 15421:2006 [5], was published only in 2006. However, modern ductile design principles, such as capacity-based design and special detailing rules (see Fardis [6]), were not included in the code. Before 2006, seismic loads have been traditionally considered only in special structures such as nuclear power plants (Santos and Lima [7]). A survey conducted by Miranda et al. [8] indicates that, even after ABNT NBR 15421:2006, seismic design may not have been properly considered by engineers for several reasons such as the lack of studies showing its importance. Moreover, the inconsistencies in the provisioned design acceleration map zones outlined by recent preliminary maps and some researchers ([2], Lopes and Nunes [9], Dourado [10], Petersen et al. [11], Nóbrega et al. [12]), as well as the possibility of induced earthquake events (Barros et al. [13], Silva et al. [14]), indicate that buildings in some regions may experience ground motions intensities higher than they were designed for.

Despite the possibility of potentially damaging earthquakes in Brazil, studies regarding the seismic assessment of the buildings in the country are still scarce. Structural seismic performance, as well as the adequacy of code provisions, can be assessed by means of reliability analyses using fragility functions (FF) and hazard curves. The former depicts the conditional probability that a structure will exceed a limit-state for various levels of ground shaking represented by an intensity measure (IM) (Siqueira et al. [15]), whereas the latter depicts the mean annual frequency of exceedance of the IM levels for the structure's site (McGuire [16]); both concepts are present in the performance-based earthquake engineering context and can be used to assess the failure probability of a structure during its lifetime (Krawinkler [17]).

Fragility functions can be empirical-based or analytical-based. The empirical-based FF can be derived using past earthquake survey damage reports, whereas the analytical-based FF are obtained through numerical analyses, especially for low seismic activity regions [15], e.g., Brazil, where field data of earthquakes is insufficient. Hazard curves are derived through probabilistic seismic hazard analysis (PSHA) of a specific region or site [16]. While there are a few PSHA studies for Brazil ([2], [10], [11], Souza et al. [18], Almeida et al. [19], Borges et al. [20], Alves [21], Nóbrega et al. [22]), studies focusing on fragility functions are currently lacking, as can be observed in the database presented in Silva et al. [23], although several were conducted worldwide (Ramamoorthy et al. [24], Ellingwood et al. [25], Ramamoorthy et al. [26], Kappos and Panagopoulos [27], Rajeev and Tesfamariam [28], Jeon et al. [29], Amirsaradi et al [30]).

This study aims to develop fragility functions for a reinforced concrete (RC) framed structure designed according to the Brazilian code ABNT NBR 6118:2014 [31] but with no earthquake resistant design, and perform its reliability assessment. Non-linear dynamic analyses using ground motion records are performed on finite element models of the $\mathrm{RC}$ structure to estimate the seismic demand. Fragility functions are then generated, and the failure probability for three limit states in a 50-year period is assessed by their convolution with seismic hazard curves for Northeastern Brazil. The results provide insight on the adequacy of the analyzed building in different locations through a regional failure probability map.

\section{RELIABILITY ANALYSIS AND FRAGILITY FUNCTIONS METHODOLOGY}

Within the framework of the performance-based earthquake engineering, structural performance can be defined as the probability that the seismic demand (D) on a structural system exceeds its structural capacity (C) (Cornell et al. [32]), which can also be stated in terms of fragility functions for several levels of ground motions intensity measure (IM). Both $\mathrm{D}$ and $\mathrm{C}$ inherently follow a distribution function due to uncertainties in ground motions characteristics (i.e., record-to-record variability), in material properties, geometry, construction quality, and modelling issues [26]; and, therefore, a probabilistic approach is required. Under the common assumption that the demand, the 
capacity, and the fragility function follow lognormal distributions, the structural fragility of a system can be computed in a closed-form expression as follows (Equation 1):

$$
P[D \geq C \mid I M]=\Phi\left[\frac{\ln \left(\frac{S_{D}}{S_{C}}\right)}{\sqrt{\sigma_{D \mid I M}^{2}+\sigma_{C}^{2}+\sigma_{M}^{2}}}\right]
$$

Where $\Phi$ is the standard normal cumulative distribution function; $S_{D}$ and $\sigma_{D \mid I M}$ are the median and logarithmic dispersion of the seismic demand, respectively; $\mathrm{S}_{\mathrm{C}}$ and $\sigma_{\mathrm{C}}$ are the capacity's median and dispersion, respectively; and $\sigma_{\mathrm{M}}$ represents the uncertainty in modelling the structural, e.g., non-simulated collapse modes. Note that the dispersion $\sigma$ may also be referred as $\beta$ in the literature, but herein we adopted $\sigma$ to avoid confusion with the reliability index symbol (discussed later in this section).

The probabilistic parameters of the demand $\left(\mathrm{S}_{\mathrm{D}}\right.$ and $\left.\sigma_{\mathrm{D} \mid \mathrm{IM}}\right)$ are obtained by means of a cloud analysis (Jalayer et al. [33]), which consists in performing non-linear dynamic analyses using unscaled ground motion records on numerical models of the structure. Each model is generated considering materials and system's properties as random variables, whose values are sampled from their distribution using Latin Hypercube Sampling (McKay et al. [34]), and is randomly paired with each ground motion, as performed by Celik and Ellingwood [35]. The adopted random variables are indicated in Table 1: concrete strength $\left(f_{c}\right)$, yield strength of longitudinal reinforcement $\left(f_{y}\right)$, yield strength of transverse reinforcement $\left(\mathrm{f}_{\mathrm{yw}}\right)$, modulus of elasticity of reinforcement $\left(\mathrm{E}_{\mathrm{s}}\right)$, and damping ratio $(\zeta)$. The values in Table 1 should not be confused with the parameters used in design that consider characteristic values of materials strength and/or adopt code-prescribed values.

Table 1. Random variables adopted.

\begin{tabular}{ccccc}
\hline Determination & Distribution & Mean & Coefficient of variation & Reference \\
\hline$f_{\mathrm{c}}(\mathrm{MPa})$ & Normal & 33.01 & 0.15 & Nogueira [36] \\
\hline $\mathrm{f}_{\mathrm{y}}(\mathrm{MPa})$ & Normal & 576.00 & 0.08 & Nogueira [36] \\
\hline$f_{\mathrm{yw}}(\mathrm{MPa})$ & Normal & 690.93 & 0.08 & Nogueira [36] \\
\hline$E_{\mathrm{s}}(\mathrm{GPa})$ & Normal & 201.00 & 0.033 & Mirza and MacGregor[37] \\
\hline$\zeta$ & Log-normal & 0.042 & 0.76 & Healey et al. [38] \\
\hline
\end{tabular}

The maximum structural demand and the intensity measure of each simulation are related through a linear regression in the logarithmic space to determine the Probabilistic Seismic Demand Model (PSDM); that is, $\mathrm{S}_{\mathrm{D}}$ and $\sigma_{\mathrm{D} \mid \mathrm{IM}}$. Based on [32], the relation between $\mathrm{S}_{\mathrm{D}}$ and IM is assumed to follow the power law in Equation 2, which can be restated in the logarithmic space through Equation 3. The coefficients $a$ and $b$ are obtained directly from the linear regression, whereas $\sigma_{\mathrm{D} \mid \mathrm{IM}}$ is obtained by Equation 4 , where $\mathrm{N}$ is the number of simulations and di is the maximum demand on the structure.

$S_{D}=a(I M)^{b}$

$\ln \left(S_{D}\right)=\ln (a)+b \cdot \ln (I M)$

$\sigma_{D \mid I M}=\sqrt{\frac{\sum\left(\ln \left(d_{i}\right)-\left(\ln \left(a(I M)^{b}\right)\right)^{2}\right.}{N-2}}$ 
Herein, the spectral acceleration fixed at the $1 \mathrm{~s}$ period, $\mathrm{Sa}(\mathrm{T}=1 \mathrm{~s})$, is adopted as the intensity measure (IM). It is chosen because there are large scale seismic hazard studies for South America using this IM [11], from which we can obtain the hazard curves. Moreover, the authors evaluated other two IM available from the hazard curves by [11]: peak ground acceleration and spectral acceleration fixed at the $0.2 \mathrm{~s}$ period; both performed poorer than the adopted IM considering the proficiency and the sufficiency criteria described in Padgett et al. [39] and in Du et al. [40], thereby were excluded.

Ground motion records are applied in both orthogonal horizontal directions of the numerical model, therefore the geometric mean of the two orthogonal components is used as IM (Baker and Cornell [41]). The demand on the structure is measured by the inter-story drift ratio (IDR) observed during analysis among all floors, since it is well related to structural damage and have also been adopted by several researchers and design standards ([24], [25], Whittaker et al. [42]). IDR is defined by the relative displacements between floors divided by the floor height; the maximum IDR value observed among all floors in the analysis represents the seismic demand.

The structural capacity (C) can be defined as the maximum response that a structure can withstand without reaching a limit state (Wen et al. [43]). Three limit states are considered: Immediate Occupancy (IO), Life Safety (LS) and Collapse Prevention (CP). These limit states are qualitatively described in terms of building performance and functionality by ASCE/SEI 41-17 [44] (Table 2), in which the damage pattern observed depicts consequences that are readily identifiable in post-earthquake situations, and are meaningful to society. In addition, they have been widely adopted by researchers; thus, their use herein facilitates further comparisons with other works [35]. Other limit states related to structural and nonstructural damage, repairment measures and down-time can be found elsewhere ([24], FEMA P-58-1 [45], HAZUS MH-R1 [46]).

Table 2. Qualitative description of the limit states.

\begin{tabular}{ccc}
\hline Limit state & Description \\
\hline Immediate Occupancy (IO) & $\begin{array}{c}\text { No permanent drift. Structure substantially retains its original strength and stiffness. Equipment and contents are } \\
\text { generally secure but might not operate due to mechanical failure or lack of utilities. Some cracking of facades, } \\
\text { partitions, and ceilings. Elevators can be restarted. Fire protection operable. Continued occupancy likely. }\end{array}$ \\
\hline Life Safety (LS) & $\begin{array}{c}\text { Some residual strength and stiffness left in all stories. Gravity-load-bearing elements function. Building might } \\
\text { not be economical to repair. Falling hazards, such as parapets, mitigated, but many architectural, mechanical, } \\
\text { and electrical systems are damaged. Continued occupancy might not be likely before repair. }\end{array}$ \\
\hline Collapse Prevention (CP) & $\begin{array}{c}\text { Small residual stiffness and strength to resist lateral loads, but gravity load-bearing columns function. Large } \\
\text { permanent drifts. Some exits blocked. Extensive damage to nonstructural components. Infills and parapets failed } \\
\text { or at incipient failure. Building is near collapse in aftershocks and should not continue to be occupied. }\end{array}$ \\
\hline
\end{tabular}

Values of $\mathrm{S}_{\mathrm{C}}$ for IO, LS and CP are adopted as $0.5 \%, 1.0 \%$ and $2.0 \%$, according to [24]. The same value of 0.3 is assumed for $\sigma_{\mathrm{C}}$ for all limit states, and also for $\sigma_{\mathrm{M}}$, as suggested by [43]. One should note that adopting the same $\sigma_{\mathrm{C}}$ for all limit states is a simplification, since higher limit states present a greater uncertainty due to the complexity of structural behavior with the failure approximation (Tavares et al. [47]).

The fragility function and its lognormal parameters can then be determined from Equation 5 following a substitution of the linear regression parameters (see Equation 3). The values of $\theta$ and $\sigma$ in Equations 6 and Equation 7 are the fragility functions' median and dispersion, respectively.

$P[L S \mid I M]=\Phi\left[\frac{\ln (I M)-\frac{\ln \left(S_{C}\right)-\ln (a)}{b}}{\frac{\sqrt{\sigma_{D \mid I M}^{2}+\sigma_{C}^{2}+\sigma_{M}^{2}}}{b}}\right]$

$\theta=\exp \left(\frac{\ln \left(S_{C}\right)-\ln (a)}{b}\right)$

$\sigma=\frac{\sqrt{\sigma_{D \mid I M}^{2}+\sigma_{C}^{2}+\sigma_{M}^{2}}}{b}$ 
Once the fragility functions are defined, the mean annual frequency of exceedance of the limit state $i\left(\lambda_{i}\right)$ is computed using the basic reliability theorem in Equation 8 (Melchers and Beck [48]), where $F_{c}(I M)$ is the fragility function and $\mathrm{f}_{\mathrm{d}}(\mathrm{IM})$ is the derivative of a hazard curve. The annual probability of failure $\left(\mathrm{p}_{\mathrm{f}}\right)$ over a period of time $\mathrm{t}$ is determined according to Equation 9, and the Reliability Index ( $\beta$ ) according to Equation 10 . The obtained values of $\mathrm{p}_{\mathrm{f}}$ and $\beta$ can be compared to prescribed acceptance criteria found in literature or codes to check if the structural safety is adequate or not. A summary of the methodology is presented in Figure 1.

$\lambda_{i}=\int_{I M} F_{C, i}(I M) f_{d}(I M) d I M$

$p_{f}=1-e^{-\lambda \cdot t}$

$\beta=-\Phi^{-1}\left(p_{f}\right)$

The hazard curves developed by [11] are adopted herein, because they are publicly available for several geographic coordinates in South America, and ready for use in engineering applications, unlike the results of other hazard studies in Brazil. A class D soil is considered in this study; therefore, the accelerations must be amplified, because the reference soil in [11] is the limit between classes B and C. The soil amplification factors of ASCE/SEI 7-16 [49] are used for this, since the reference soil is the same. The hazard curves and the generated fragility functions paper are applied in Equation 8 to estimate the failure probability of the RC building at a regional scale in Northeastern Brazil, selected due to the relatively higher seismicity of this region. Maps of the estimated failure probability for the three limit states are generated to depict where the structure would experience unacceptable performance according to the criteria reported in the literature.

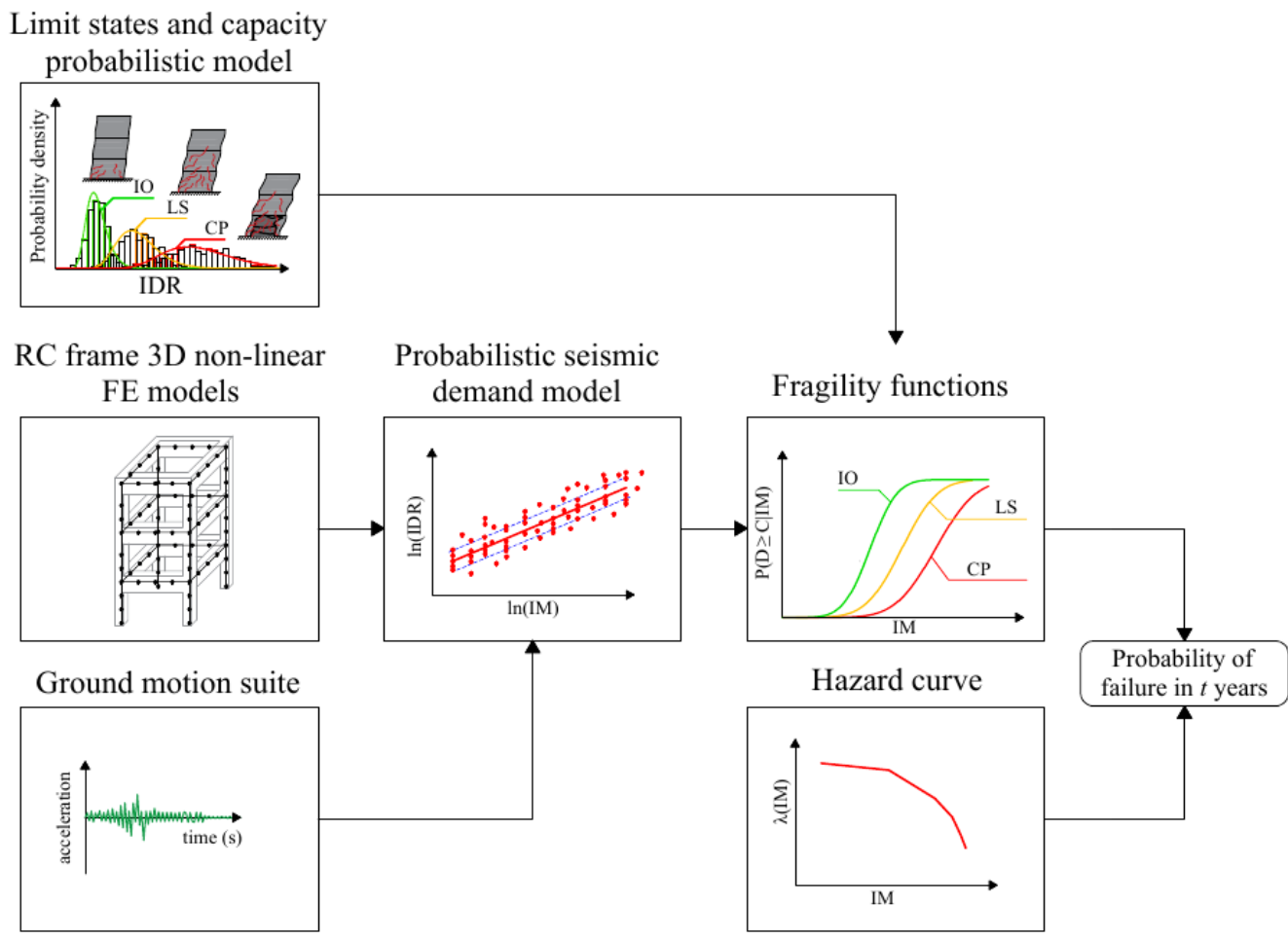

Figure 1. Summary of analytical seismic fragility and reliability analysis methodology.

Herein, the $\beta$ values adopted by Priyadarshini et al. [50] are selected to evaluate the adequacy of the analyzed structure for each limit state (Table 3). These values are somewhat consistent and less conservative than the ones proposed by the Probabilistic Model Code [51] and ISO 2394 [52]. Regarding Collapse Prevention, they are more conservative than the one required by [49] (i.e., $\mathrm{p}_{\mathrm{f}}$ of $1 \%$ in 50 years), but less conservative than other values used to generate seismic design maps in 
other countries (see Silva et al. [53]). Accordingly, the selected values represent a compromise between the less and more restrictive criteria found in the literature. The acceptable reliability depends on the consequences of failures and the cost of mitigating measures, as well as any other variables that somehow affect society, consequently the required reliability for hospitals or taller buildings, for example, should be more stringent. The values of $\mathrm{p}_{\mathrm{f}}(\mathrm{t}=50$ years $)$ in Table 3 are used afterwards to verify if the expected seismic performance of the building described in the next section is adequate or not.

Table 3. Acceptance criteria in terms of annual failure probability $\left(\mathrm{p}_{\mathrm{f}}\right)$ and reliability index $(\beta)$ for each limit state.

\begin{tabular}{cccc}
\hline Limit state & $\boldsymbol{\beta}(\mathbf{t}=\mathbf{1}$ year $)$ & $\mathbf{p}_{\mathbf{f}}(\mathbf{t}=\mathbf{1}$ year $)$ & $\mathbf{p}_{\mathbf{f}}(\mathbf{t}=\mathbf{5 0}$ year $)$ \\
\hline IO & 2.5 & 0.0062 & 0.2666 \\
LS & 3.0 & 0.0013 & 0.0629 \\
\hline CP & 4.0 & $3.167 \cdot 10^{5}$ & 0.0016 \\
\hline
\end{tabular}

\subsection{Reinforced concrete building design}

A symmetrical three-story three-bay 3D RC frame designed according to ABNT NBR 6118:2014 [31] is analyzed. A lowrise building is assessed because this typology is common in the Brazilian context (e.g., [14]), and tends to be more critical for seismic loads. Taller buildings have some inherent strength already provided by the wind load design, and are generally subjected to lower seismic loads due to the higher period of vibration. The elements' cross-section and the building's dimensions (Figure 2) are not necessarily representative of a specific building class in Brazil, since this definition would require an in-depth statistical study of several real buildings, which it is out of the scope of this paper; however, the adopted characteristics are enough to provide an overview of the expected seismic performance of low-rise frames. The number of bays has minor influence on the dynamic response of RC frames (Gkimprixis et al. [54]), hence three bays are assumed. Future studies should focus on other type of structures with different designs, and the consideration of masonry infills and soil-structure interaction.

The structure is for residential use, designed considering wind $(30 \mathrm{~m} / \mathrm{s}$ basic speed) and out-of-plumbness as lateral loads, presents a C25 concrete class, and CA-50 and CA-60 steel reinforcement. No seismic provisions were considered, as it is the purpose of this work. Details concerning the elements' cross-section and the floor plan dimension are presented in Figure 2. All columns present $4 \varnothing 10.0 \mathrm{~mm}$ as longitudinal reinforcement, equivalent to a $0.50 \%$ reinforcement ratio, and $\varnothing 5.0 \mathrm{~mm}$ stirrups every $12 \mathrm{~cm}$ as transverse reinforcement. For beams, the longitudinal reinforcement ratio ranges from $0.42 \%$ to $1.28 \%$ depending on the beam and the section's position in the span, and the shear design resulted in the minimum shear reinforcement ratio required by the code.

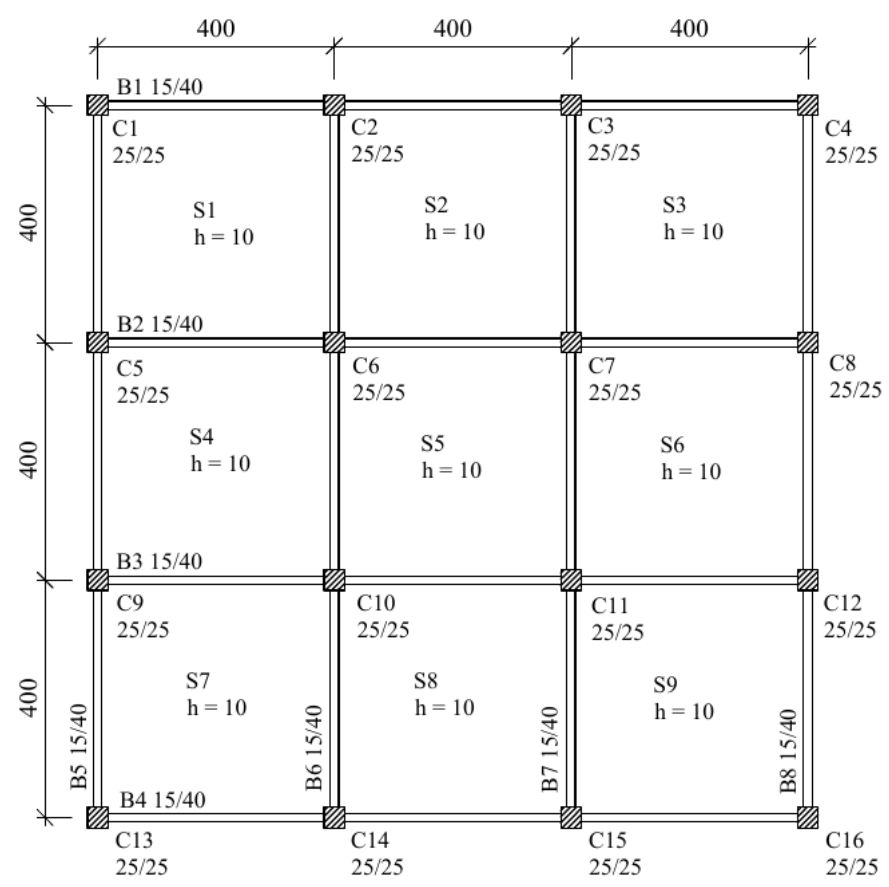

Figure 2. Designed floor plan, dimensions (in centimeters), and structural elements (not in scale). 


\subsection{Numerical model}

Three-dimensional finite element models of the framed structure are generated in OpenSees (McKenna et al. [55]) (Figure 3). Reinforced concrete elements are modelled with displacement beam-column elements with spread plasticity and fiber sections; each beam and column with five and three finite elements, respectively. This modelling approach enables one to consider the confined concrete section core and unconfined concrete cover, as well as the longitudinal reinforcement, and the effect of physical non-linearities along the elements' length. Vertical loads are uniformly distributed along beams and calculated according to the tributary area considering the combination $1.1(\mathrm{D}+0.25 \mathrm{~L})$, as per [44], where D and L are the dead loads and live loads, respectively. Masses are lumped into column's nodes at floor level, and calculated according to the same combination. A modal analysis of the building's numerical model revealed a mean fundamental period of 0.60 seconds.

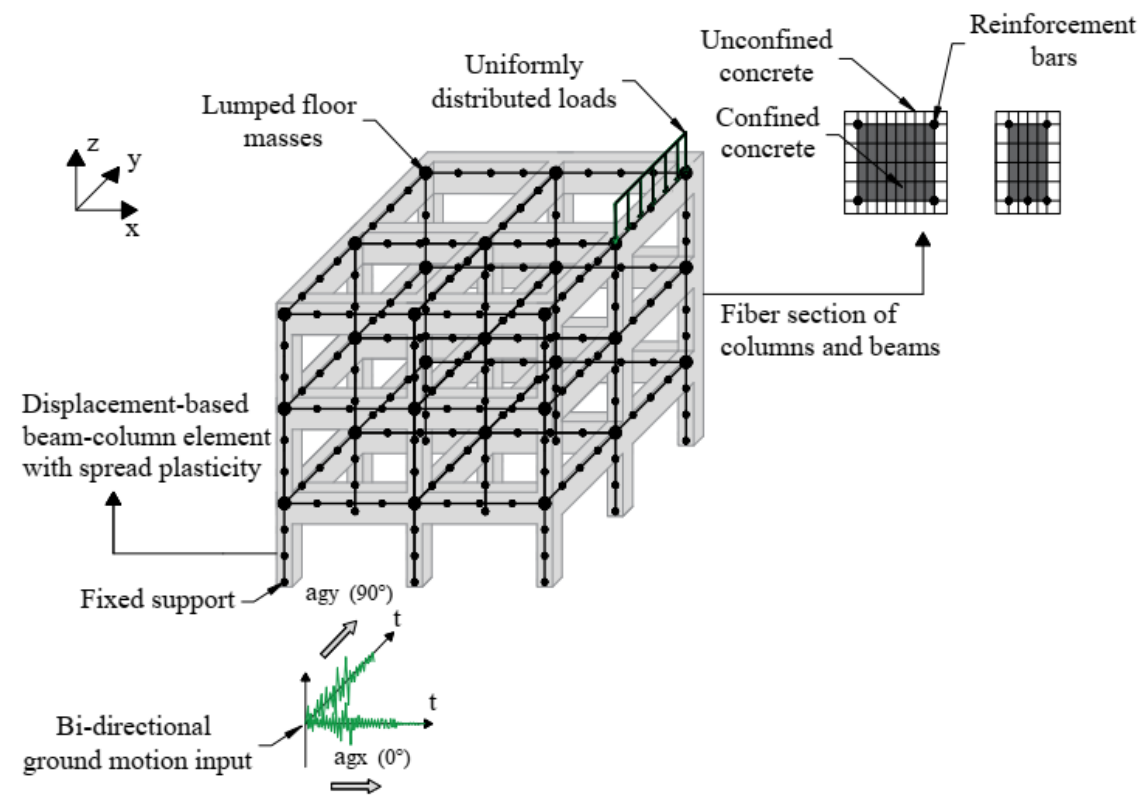

Figure 3. Summary of numerical model: elements, fiber cross-section, vertical loads, masses, and bi-directional ground motion input.

Confined and unconfined concrete constitutive law is defined according to Chang and Mander [56]. Steel material is modelled according to Giuffré-Menegetto-Pinto law with isotropic strain-hardening (Filippou et al. [57]), whose parameters are defined based on the mean values proposed by Carreño et al. [58] (Figure 4). The adequacy of the finite element model's response was verified by comparison with cyclic load experiments of simpler frames. Information on this can be found in Pereira [59].

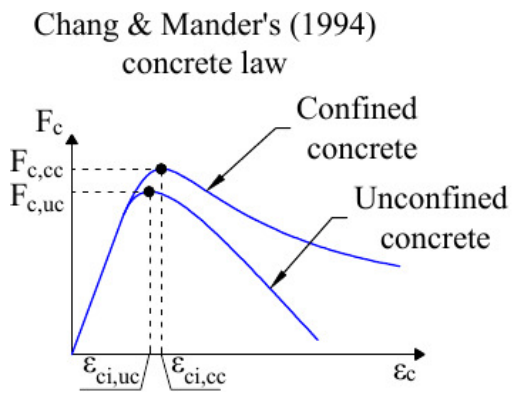

$$
\begin{aligned}
& \text { Giuffré-Menegotto-Pinto } \\
& \text { steel law }
\end{aligned}
$$

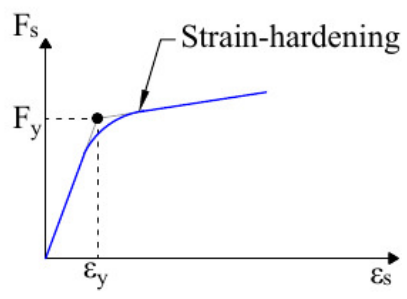

Figure 4. Generic representation of concrete and steel material law.

\subsection{Ground motion records}

The ground motion suite adopted to perform the dynamic analyses is the one used by Medina and Krawinkler [60], as it has been used by other researchers worldwide (Mehanny and El Howary [61]). The adopted suite consists of 
80 recorded ground motion (GM) pairs from western United States earthquakes with two orthogonal components in the horizontal directions; it presents magnitude and closest distance to fault rupture (R) ranging from 5.5 to 7.0 and $13 \mathrm{~km}$ to $60 \mathrm{~km}$, respectively, and it was recorded in Soil Class D. The GM suite is extracted from the PEER NGA-West2 database (Ancheta et al. [62]). The geometric mean of the two orthogonal components of all the individual records, along with the median and 10th and 90th percentile, are presented in Figure 5.

This suite is adopted because it presents some desirable attributes for this study. The lower distance limit avoids nearfault type events, whereas the upper limit minimizes the effect of different seismic attenuation between different regions, which is important since the records are not from Brazil. Also, the response spectrums ordinate ranges from more frequent to rarer expected accelerations in Brazil associated with different return periods such as 72,475 and 2475 years, which is important to ensure the effectiveness of the linear regression [33]. It is also worth mentioning that the upper magnitude boundary is consistent with previous seismic hazard assessment studies performed for Brazil [11], [18]-[20].
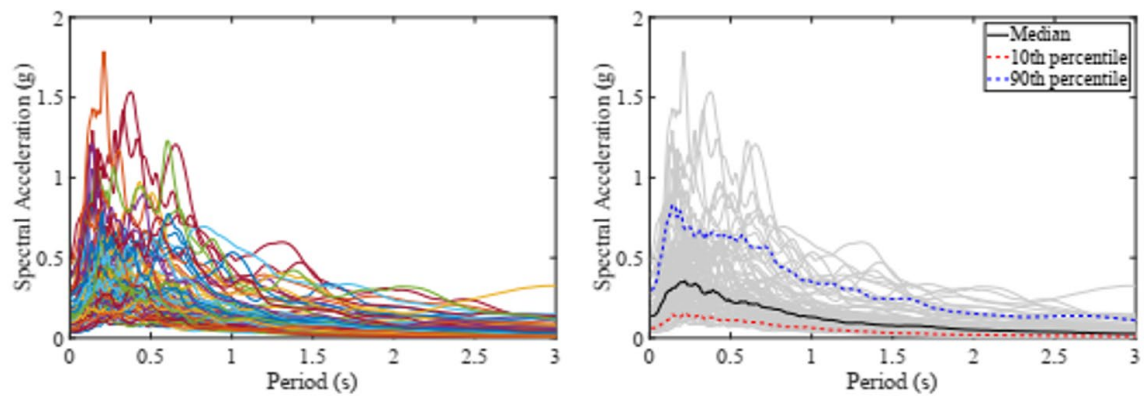

Figure 5. Response spectrum of all records (left) and median, 10th percentile, and 90th percentile of the ground motion suite spectral accelerations (right).

In addition, the adopted intensity measure attends the sufficiency criteria, as mentioned in Section 2. A sufficient IM helps to ensures an accurate estimate of the demand ([D|IM]), irrespective of the values of magnitude and distance of the adopted ground motion suite, and the validity of Equation 8 ([39], Luco and Cornell [63]); thus, the magnitude range of the GM suite does not strongly influence the results.

Ideally, the GM used in analyses should be recorded in tectonically similar regions (Bommer and Acevedo [64]); however, GM for stable continental regions such as Brazil are not widely available, thereby records from tectonically active regions worldwide, artificially-generated ones, or scaled records from stable regions are commonly adopted. Artificial records for Brazil are not readily available, to the best of our knowledge, and their development is out of the scope of this paper. Scaling of records from stable regions could result in excessive scale factors, and introduce some bias in the analysis that we intend to avoid. Hence, the natural records from tectonically active regions by [60] are adopted; nevertheless, we acknowledge that further discussion on the issue of ground motion selection is necessary.

\section{RESULTS AND DISCUSSIONS}

The probabilistic seismic demand model (PSDM) and the fragility function (FF) are presented in Figure 6. The median values $(\theta)$ of the FF for IO, LS and CP are $0.1214,0.2005$, and 0.3313 , and the dispersion $(\sigma)$ is 0.4648 . These parameters are important to reproduce the fragility functions in future seismic risk or reliability studies.
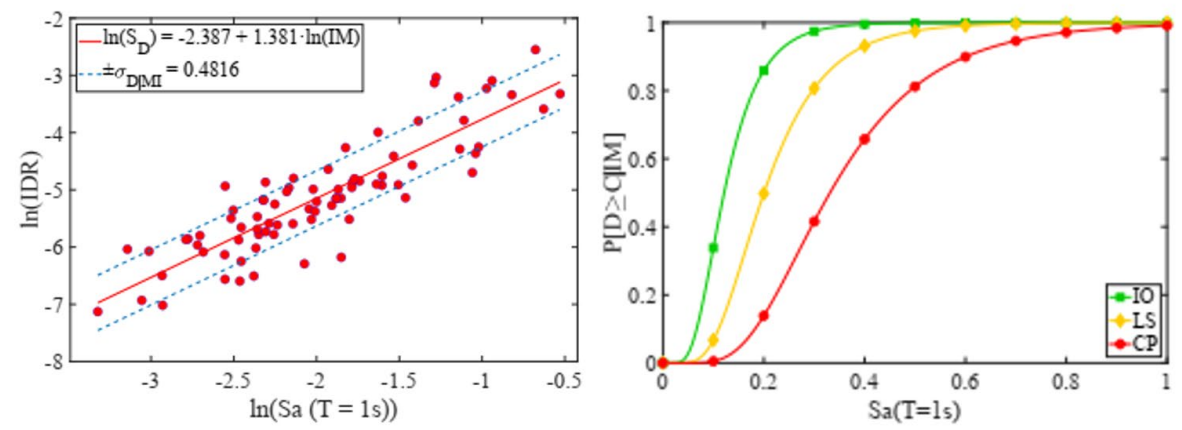

Figure 6. Probabilistic Seismic Demand Model (PSDM) (left) and fragility functions (right) of the analyzed RC structure. 
The FF are integrated with the hazard curves developed by Petersen et al. [11] for Northeastern Brazil using Equation 8, and a failure probability map for each limit state is plotted for in Figure 7, where the orange and the blue colors shades refers to the regions where the structure would depict inadequate and adequate failure probability, respectively, according to the criteria described in Section 2. For the Immediate Occupancy limit state, Figure 7a indicates that the structure outperforms the acceptance criteria in the entire Northeastern region. Nevertheless, probabilities up to $25 \%$ are obtained; thereby in situations in which non-structural elements are important to building functionality (e.g., hospitals), one should be aware that this value is somewhat high and may represent a threat. The same is valid for Life Safety (Figure 7b), which there is a relatively small zone among the states of Paraíba (PB) and Rio Grande do Norte (RN) where an inadequate failure probability is observed, with values up to $12 \%$, almost twice the acceptable value.

Regarding Collapse Prevention (Figure 7c), however, a large area with unacceptable failure probability is noticed, which implies that the building design is not enough to guarantee an adequate performance. A maximum probability of $6 \%$ in 50 years is observed, which is a considerable high value about 38 times the acceptable limit. An area in the southwest of the state of Bahia (BA) shall be highlighted, since it its located in Zone 0 of ABNT NBR 15421:2006 [5], i.e., seismic design is not required, but a large zone with unacceptable failure probability is observed, which indicates a possible region where seismic design should in fact be considered. Failure probability in this area reaches about $3 \%$ in 50 years. On the other hand, the upper zone of the studied region is consistent with the Zone 1 of the code, where seismic design is required.

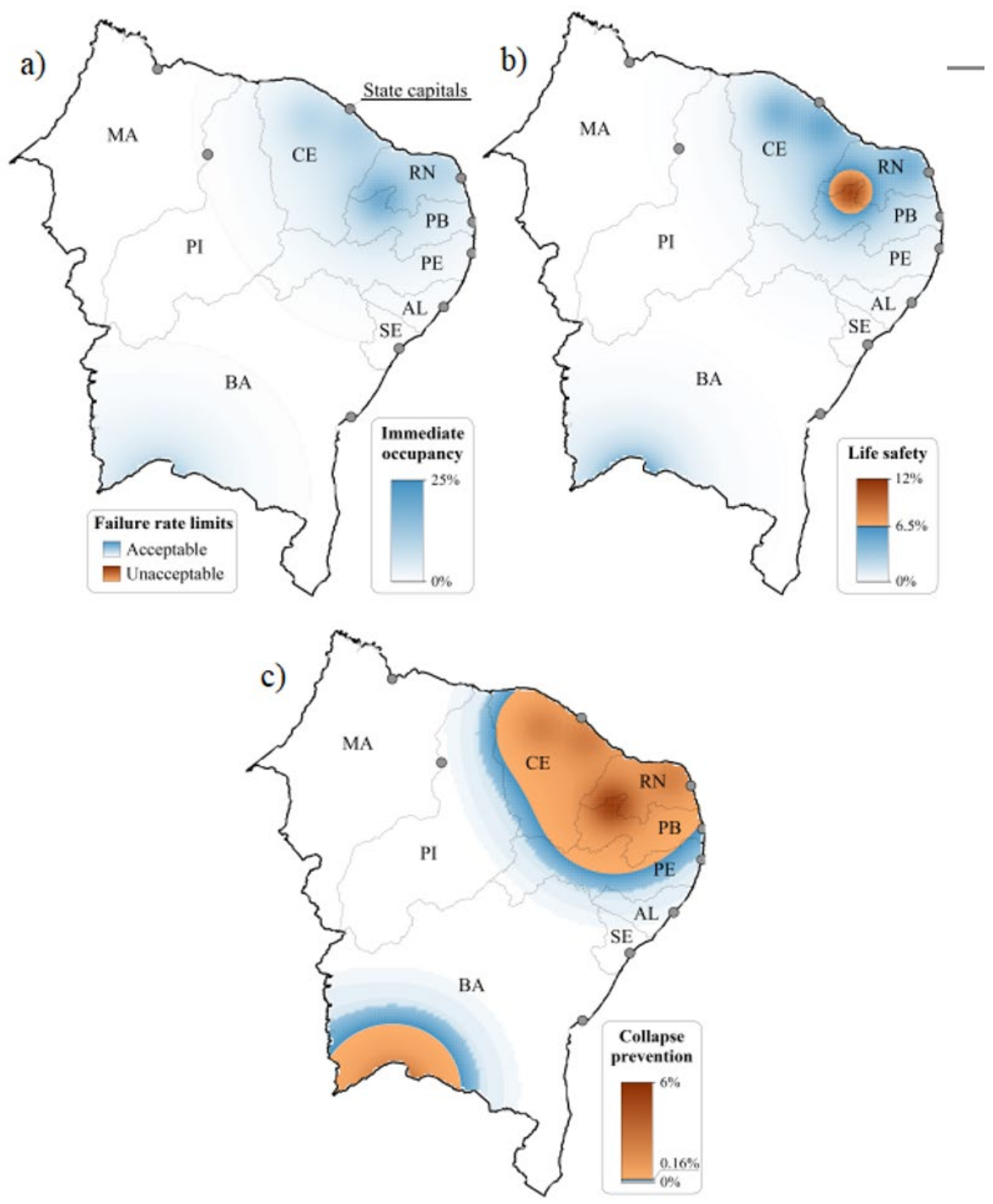

Figure 7. Failure probability maps considering a 50-year period: a) Immediate Occupancy; b) Life Safety; c) Collapse Prevention. 
The maps in Figure 7 depicts the failure probability given the structure is built in those regions. A large part of Northeastern region, notwithstanding, comprises low population density cities, whose constructions are not-engineered houses, thus an engineered three-story building is unlikely. Despite that, two highly populated state capitals (Fortaleza in $\mathrm{CE}$, and Natal in RN) are located within the unacceptable probability zone in Figure 7. For these cities, Collapse Prevention failure probability resulted even higher than $1 \%$ in 50 years which corresponds to the less conservative acceptance criteria of [49] mentioned in Section 2.

One should note that the maps were generated considering soil class D. Different soils amplify differently the ground accelerations, thereby the expected failure probability depends on the soil class of the building's site. The probabilities considering a soil class $\mathrm{C}$ are expected to be approximately half of those for soil class D, whereas for soil class $\mathrm{B}$ approximately five times smaller. For very soft soils (i.e., soil class E), the probabilities are expected to be on average two times higher. The fragility functions should obviously be different, since they were generated considering records from soil class D, but the largest influence should come from the hazard curves, so that the aforementioned estimates are enough to give an idea of what to expect. Regardless, the big picture would not change, and an unacceptable collapse probability would still be observed in a large area in the upper Northeastern, in spite of a much smaller area in the southwest of BA state, for all soil classes.

An issue outlined by the maps is the presence of a relatively higher seismicity among the states of Paraíba (PB) and Rio Grande do Norte (RN), responsible especially for the unacceptable performance for Life Safety (Figure 7b). Based on the available earthquake catalog, and other preliminary PSHA studies in Brazil, for example [2], we should point out that the relatively higher hazard in this particular zone seems inconsistent, and can be a consequence of the methodology adopted by [11]. In [11], the maps are generated using the smoothed seismicity-based seismic sources, which depends directly on the location of past earthquakes occurrence. The use of international catalogs (hence less precise values of magnitudes and epicenter location) likely influenced the generation of this zone. In [2], the maps are generated using the same methodology, but with a national catalog, combined with seismic sources defined based on expert judgment. The final map does not highlight this zone. Therefore, we believe that the failure probability in that region is overestimated. Despite that, the proposed accelerations values between both are similar for the rest of the upper Northeastern, thus similar failure probabilities would be expected. The point of this discussion is not to discredit the work by [11], but to highlight the importance and the need for more national PSHA studies in Brazil. In addition, one should be aware that the reference soil class of the both works are different, therefore any comparisons must be made following the application of soil amplification factors to correct the accelerations.

\section{CONCLUSIONS}

Brazil, although located in a seismically stable continental region, is prone to small-to-moderate earthquakes, strong enough to inflict structural and non-structural damage if buildings are not seismic designed. Reliability studies are essential to provide information regarding the performance of the structures under loads such as earthquakes, and if they meet the diverse needs of society, for instance, different limit states. In addition, important information on how to improve structural performance can be obtained.

However, studies focusing on the seismic reliability of the buildings designed according to Brazilian code provisions are still scarce. Herein, a three-story RC framed structure, designed according to ABNT NBR 6118:2014 but with no earthquake resistant design, is evaluated. Fragility functions were generated using non-linear dynamic analyses, and the failure probability of the structure was assessed considering different regions of Northeastern Brazil through combining the fragility with the hazard curves developed by Petersen et al. [11].

From the results it is possible to point out that the structure does not comply with Collapse Prevention structural requirements in several locations, and reaches considerable high values of failure probability. This result highlights the importance and the need for earthquake-resistant design in Brazil, since in a considerable area of Northeastern Brazil the collapse probability resulted unacceptable, including two state capital cities. Life Safety failure probability is inadequate in a much smaller area, whereas for Immediate Occupancy the building's performance is acceptable. The results also bring awareness about the need for more rigorous seismic provisions in zones where design requirements are minimum and/or non-existent, i.e., the Zone 0 of ABNT NBR 15421:2006.

Further research can provide more information for the improvement of acceleration design maps zoning, or demonstrate their adequacy, and provide information to improve seismic design provisions. The results in this paper should be improved as new PSHA for Brazil are developed. 


\section{ACKNOWLEDGEMENTS}

This study was financed in part by the Coordenação de Aperfeiçoamento de Pessoal de Nível Superior - Brasil (CAPES) - Finance Code 001; and by the São Paulo Research Foundation (FAPESP) - Finance Code 2018/23304-9. The authors would also like to thank the company TQS Informática Ltda., and Prof. Dr. Petrus Nóbrega for providing the academic version of the software CAD/TQS V21 used to design the building in this paper.

\section{REFERENCES}

[1] J. Berrocal et al. Sismicidade do Brasil. São Paulo, Brazil: Esperança, 1984.

[2] M. S. Assumpção, M. Pirchiner, J. Dourado, and L. Barros “Terremotos no Brasil: preparando-se para eventos raros," Boletim SBGf, vol. 96, pp. 25-29, 2016. Accessed: May 2, 2021. [Online]. Available: https://sbgf.org.br/noticias/images/Boletim_96-2016.pdf

[3] C. I. Nievas, J. J. Bommer, H. Crowley, J. van Elk, M. Ntinalexis, and M. Sangirardi, "A database of damaging small-to-medium magnitude earthquakes," J. Seismol., vol. 24, no. 2, pp. 263-292, 2020., http://dx.doi.org/10.1007/s10950-019-09897-0.

[4] M. Takeya, J. Ferreira, R. Pearce, M. Assumpção, J. Costa, and C. Sophia, "The 1986-1988 intraplate earthquake sequence near João Câmara, northeast Brazil—evolution of seismicity," Tectonophysics, vol. 167, no. 2-4, pp. 117-131, 1989., http://dx.doi.org/10.1016/0040-1951(89)90062-0.

[5] Associação Brasileira de Normas Técnicas, Projeto de Estruturas Resistentes a Sismos - Procedimento, ABNT NBR $15421,2006$.

[6] M. N. Fardis, "Capacity design: Early history," Earthquake Eng. Struct. Dynam., vol. 47, no. 14, pp. 2887-2896, 2018., http://dx.doi.org/10.1002/eqe.3110.

[7] S. H. Santos and S. S. Lima "Subsídios para uma futura normalização brasileira para resistência anti-Sísmica das estruturas de concreto de edifícios," IBRACON, vol. 1, no. 1, pp. 47-62, 2005. Accessed: May 2, 2021. [Online]. Available: http://www.ibracon.org.br/publicacoes/revistas_ibracon/rev_estruturas/V1/RIEst_2004_0023-02br-v.01.pdf

[8] P. S. T. Miranda, H. S. A. Varum, and N. S. Vila-Pouca "Reflexões sobre o risco sísmico no Brasil," in Proc. $11^{\circ}$ Congresso Nacional de Sismologia e Engenharia Sísmica, 2019. Accessed: May 2, 2021. [Online]. Available: https://repositorioaberto.up.pt/bitstream/10216/133985/2/422679.pdf

[9] A. E. V. Lopes and L. C. Nunes, "Intensidades sísmicas de terremotos: formulação de cenário sísmico no Brasil," Revista USP, no. 91, pp. 90-103, 2011, https://doi.org/10.11606/issn.2316-9036.v0i91p90-103

[10] J. C. Dourado “Mapa de ameaça sísmica do Brasil," in Proc. $47^{\circ}$ Congresso Brasileiro de Geologia, Set. 2014.

[11] M. D. Petersen et al., "Seismic hazard, risk, and design for South America," Bull. Seismol. Soc. Am., vol. 108, no. 2, pp. 781-800, 2018. http://dx.doi.org/10.1785/0120170002.

[12] P. G. B. da Nóbrega, B. R. S. Souza, and M. L. C. Felipe "Sobre os mapas de perigo sísmico para o projeto de estruturas," in Proc. $61^{\circ}$ Congresso Brasileiro do Concreto, Out. 2019. Accessed: May 2, 2021. [Online]. Available: https://www.researchgate.net/publication/336672092

[13] L. Barros, M. Assumpção, V. Ferreira, and L. Ribotta "Sismicidade induzida por reservatório: casos brasileiros," Bull. Brazilian Geophys. Soc., vol. 96, pp. 16-21, 2016. Accessed: May 2, 2021. [Online]. Available: https://sbgf.org.br/noticias/images/Boletim_962016.pdf

[14] A. H. Silva, G. L. Pita, J. A. Inaudi, and L. C. Vieira Jr, "Induced earthquake damage assessment methodology for potential hydraulic fracturing sites: Application to Manaus, Brazil," Earthq. Spectra, vol. 37, no. 1, pp. 180-203, 2020., http://dx.doi.org/10.1177/8755293020944178.

[15] G. H. Siqueira, A. S. Sanda, P. Paultre, and J. E. Padgett, "Fragility curves for isolated bridges in eastern canada using experimental results," Eng. Struct., vol. 74, no. 1, pp. 311-324, 2014., http://dx.doi.org/10.1016/j.engstruct.2014.04.053.

[16] R. K. McGuire, Seismic Hazard and Risk Analysis. Oakland, CA, USA: EERI, 2004.

[17] H. Krawinkler "Challenges and progress in performance-based earthquake engineering," in Int. Seminar on Seismic Engineering for Tomorrow-In Honor of Professor Hiroshi Akiyama, Nov., 1999.

[18] B. R. S. Souza, M. L. C. Felipe, P. G. B. da Nóbrega, and S. H. S. da Nóbrega "On the generation of hazard maps and response spectrum by the use of probabilistic seismic hazard analysis," in Proc. $40^{\circ}$ Ibero-Latin-American Congress of Computational Methods in Engineering, 2019. [Online]. Available: https://www.researchgate.net/publication/337304762

[19] A. A. D. de Almeida, M. S. Assumpção, J. J. Bommer, S. Drouet, C. Riccomini, and C. L. Prates, "Probabilistic seismic hazard analysis for a nuclear power plant site in southeast Brazil," J. Seismol., vol. 23, no. 1, pp. 1-23, 2019. http://dx.doi.org/10.1007/s10950-018-9755-8.

[20] R. G. Borges, M. S. Assumpção, M. C. F. de Almeida, and M. S. S. de Almeida, "Seismicity and seismic hazard in the continental margin of southeastern Brazil," J. Seismol., vol. 24, pp. 1-20, 2020. http://dx.doi.org/10.1007/s10950-020-09941-4.

[21] F. Alves “Estudo de sismicidade do Brasil para revisão da ABNT NBR 15421,” M.S. thesis, UFRJ, Rio de Janeiro, RJ, 2020. [Online]. Available: http://dissertacoes.poli.ufrj.br/dissertacoes/dissertpoli2885.pdf 
[22] P. G. B. Nóbrega, B. R. S. Souza, and S. H. S. Nóbrega, "Towards improving the seismic hazard map and the response spectrum for the state of RN/Brazil," IBRACON Struct. Mater. J., vol. 14, no. 3, pp. e14302-1-16, 2021., http://dx.doi.org/10.1590/S1983-41952021000300002.

[23] V. Silva et al., "Development of a global seismic risk model," Earthq. Spectra, vol. 36, no. 1, pp. 372-394, 2020., http://dx.doi.org/10.1177/8755293019899953.

[24] S. K. Ramamoorthy, P. Gardoni, and J. M. Bracci, "Probabilistic demand models and fragility curves for reinforced concrete frames," J. Struct. Eng., vol. 132, no. 10, pp. 1563-1572, 2006., http://dx.doi.org/10.1061/(ASCE)0733-9445(2006)132:10(1563).

[25] B. R. Ellingwood, O. C. Celik, and K. Kinali, "Fragility assessment of building structural systems in mid-america," Earthquake Eng. Struct. Dynam., vol. 36, no. 13, pp. 1935-1952, 2007., http://dx.doi.org/10.1002/eqe.693.

[26] S. K. Ramamoorthy, P. Gardoni, and J. M. Bracci, "Seismic fragility and confidence bounds for gravity load designed reinforced concrete frames of varying height," J. Struct. Eng., vol. 134, no. 4, pp. 639-650, 2008., http://dx.doi.org/10.1061/(ASCE)0733-9445(2008)134:4(639).

[27] A. J. Kappos and G. Panagopoulos, "Fragility curves for reinforced concrete buildings in greece," Struct. Infrastruct. Eng., vol. 6, no. 1-2, pp. 39-53, 2010., http://dx.doi.org/10.1080/15732470802663771.

[28] P. Rajeev and S. Tesfamariam, "Seismic fragilities of non-ductile reinforced concrete frames with consideration of soil structure interaction," Soil. Dyn. Earthquake Eng., vol. 40, pp. 78-86, 2012. http://dx.doi.org/10.1016/j.soildyn.2012.04.008.

[29] J.-S. Jeon, L. N. Lowes, R. DesRoches, and I. Brilakis, "Fragility curves for non-ductile reinforced concrete frames that exhibit different component response mechanisms," Eng. Struct., vol. 85, no. 15, pp. 127-143, 2015. http://dx.doi.org/10.1016/j.engstruct.2014.12.009.

[30] A. Amirsardari, E. Lumantarna, P. Rajeev, and H. M. Goldsworthy, "Seismic fragility assessment of non-ductile reinforced concrete buildings in Australia," J. Earthquake Eng., 2020. http://dx.doi.org/10.1080/13632469.2020.1750508.

[31] Associação Brasileira de Normas Técnicas. Projeto de estruturas de concreto - Procedimento, ABNT NBR 6118, 2014.

[32] C. Cornell, F. Jalayer, R. Hamburger, and D. Foutch, "The probabilistic basis for the 2000 SAC/FEMA steel moment frame guidelines," J. Struct. Eng., vol. 128, pp. 526-533, 2002. http://dx.doi.org/10.1061/(ASCE)0733-9445(2002)128:4(526).

[33] F. Jalayer, H. Ebrahimian, A. Miano, G. Manfredi, and H. Sezen, "Analytical fragility assessment using unscaled ground motion records," Earthquake Eng. Struct. Dynam., vol. 46, no. 15, pp. 2639-2663, 2017., http://dx.doi.org/10.1002/eqe.2922.

[34] M. D. McKay, R. J. Beckman, and W. J. Conover, "Comparison of three methods for selecting values of input variables in the analysis of output from a computer code," Technometrics, vol. 21, no. 2, pp. 239-245, 1979., http://dx.doi.org/10.1080/00401706.1979.10489755.

[35] O. C. Celik and B. R. Ellingwood, "Seismic fragilities for non-ductile reinforced concrete frames-role of aleatoric and epistemic uncertainties," Struct. Saf., vol. 32, no. 1, pp. 1-12, 2010., http://dx.doi.org/10.1016/j.strusafe.2009.04.003.

[36] C. G. Nogueira "Desenvolvimento de modelos mecânicos, de confiabilidade e de otimização para aplicação em estruturas de concreto armado," Ph.D. dissertation, USP, São Carlos, SP, Brazil, 2010. [Online]. Available: https://teses.usp.br/teses/disponiveis/18/18134/tde-29062010-113700/pt-br.php

[37] S. A. Mirza and J. G. MacGregor, "Variability of mechanical properties of reinforcing bars," J. Struct. Div., vol. 105, no. 5, pp. 921-937, 1979. http://dx.doi.org/10.1061/JSDEAG.0005146.

[38] J. Healey, S. Wu, and M. Murga, Seismic Safety Margins Research Program (Phase I). Project IV. Structural Building Response; Structural Building Response Review, New York, USA: Ebasco Services, Inc., 1980. Acessed: May 2, 2021. [Online]. Available: https://www.osti.gov/servlets/purl/5627242

[39] J. E. Padgett, B. G. Nielson, and R. DesRoches, "Selection of optimal intensity measures in probabilistic seismic demand models of highway bridge portfolios," Earthquake Eng. Struct. Dynam., vol. 37, no. 5, pp. 711-725, 2008., http://dx.doi.org/10.1002/eqe.782.

[40] A. Du, J. E. Padgett, and A. Shafieezadeh, "A posteriori optimal intensity measures for probabilistic seismic demand modeling," Bull. Earthquake Eng., vol. 17, no. 2, pp. 681-706, 2019., http://dx.doi.org/10.1007/s10518-018-0484-8.

[41] J. W. Baker and C. A. Cornell, "Which spectral acceleration are you using," Earthq. Spectra, vol. 22, no. 2, pp. 293-312, 2006., http://dx.doi.org/10.1193/1.2191540.

[42] A. Whittaker, R. Hamburger, and M. Mahoney "Performance-based engineering of buildings and infrastructure for extreme loadings," in Proc. AISC-SINY Symposium on Resisting Blast and Progressive Collapse, New York, USA, 2003. [Online]. Available: https://atcouncil.org/pdfs/Whittaker2.pdf

[43] Y. Wen, B. R. Ellingwood, and J. M. Bracci, Vulnerability Function Framework for Consequence-Based Engineering (Report 04-04). Urbana, IL, USA: MAE Center, 2004. Accessed: May 2, 2021 [Online]. Available: http://mae.cee.illinois.edu/publications/reports/Report04-04.pdf

[44] American Society of Civil Engineers. Seismic evaluation and retrofit of existing building, ASCE/SEI 41-17, 2017.

[45] Federal Emergency Management Agency, Seismic performance assessment of buildings, FEMA P-58-1, 2012.

[46] Federal Emergency Management Agency, Multi-hazard loss estimation methodology: Earthquake model, HAZUS MH-R1, 2003. [Online]. Available: https://www.hsdl.org/?abstract\&did=701264

[47] D. H. Tavares, J. E. Padgett, and P. Paultre, "Fragility curves of typical as-built highway bridges in eastern canada," Eng. Struct., vol. 40, pp. 107-118, 2012., http://dx.doi.org/10.1016/j.engstruct.2012.02.019.

[48] R. E. Melchers and A. T. Beck Structural Reliability Analysis and Prediction, 3th ed., Hoboken, NJ, USA: John Wiley \& Sons, 2018. 
[49] American Society of Civil Engineers. Minimum design loads and associated criteria for buildings and other structures, ASCE/SEI 7-16, Reston, USA, 2016.

[50] M. Priyadarshini, P. R. Davis, D. C. H. Pragalath, and P. Sarkar "Seismic reliability assessment of typical soft-storey RC building in Manipur region," Int. J. Sci. Eng. Res., vol. 4, no. 5, 2013. [Online]. Available: http://dspace.nitrkl.ac.in/dspace/bitstream/2080/2097/1/Seismic_71.pdf

[51] Joint Committee on Structural Safety. Probabilistic Model Code, Part 1, Basis of Design, JCSS-OSTL/DIA/VROU-10-11-2000, 2001.

[52] International Organization for Standardization. General principles on reliability for structures, ISO 2394, 2015.

[53] V. Silva, H. Crowley, and P. Bazzurro, "Exploring risk-targeted hazard maps for Europe," Earthq. Spectra, vol. 32, no. 2, pp. 1165-1186, 2016. http://dx.doi.org/10.1193/112514eqs198m.

[54] A. Gkimprixis, J. Douglas, E. Tubaldi, and D. Zonta "Development of fragility curves for use in seismic risk targeting," in Proc. 16th European Conf. Earthquake Eng., Thessaloniki, Greece, 2018. Acessed: May 2, 2021. [Online] Available: https://www.researchgate.net/publication/332980845

[55] F. McKenna, M. H. Scott, and G. L. Fenves, "Nonlinear finite-element analysis software architecture using object composition," J. Comput. Civ. Eng., vol. 24, no. 1, pp. 95-107, 2010., http://dx.doi.org/10.1061/(ASCE)CP.1943-5487.0000002.

[56] G. Chang and J. B. Mander, Seismic Energy-Based Fatigue Damage Analysis of Bridge Columns: Part 1-Evaluation of Seismic Capacity (Report NCEER-94-0006). Buffalo, NY, USA: NCEER, 1994. Acessed: May 2, 2021. [Online] Available: https://www.eng.buffalo.edu/mceer-reports/94/94-0006.pdf

[57] F. C. Filippou, V. V. Bertero, and E. P. Popov, Effects of Bond Deterioration on Hysteretic Behavior of Reinforced Concrete Joints (Report UCB/EERC-83/19). Berkeley, CA, USA: EERC, 1983. Acessed: May 2, 2021. [Online] Available: https://nehrpsearch.nist.gov/static/files/NSF/PB84192020.pdf

[58] R. Carreño, K. Lotfizadeh, J. Conte, and J. Restrepo, "Material model parameters for the giuffrè-menegotto-pinto uniaxial steel stress-strain model," J. Struct. Eng., vol. 146, no. 2, pp. 04019205, 2020., http://dx.doi.org/10.1061/(ASCE)ST.1943-541X.0002505.

[59] E. M. V. Pereira "Estudo da fragilidade sísmica de pórticos de concreto armado com irregularidades estruturais," M.S. thesis, Unicamp, Campinas, SP, 2021. [Online]. Available: http://repositorio.unicamp.br/handle/REPOSIP/358300.

[60] R. A. Medina and H. Krawinkler, Seismic Demands for Nondeteriorating Frame Structures and Their Dependence on Ground Motions (Report 144). Stanford, CA, USA: Blume, 2004. [Online]. Available: https://stacks.stanford.edu/file/druid:jz144cw3119/TR144_Medina.pdf

[61] S. S. F. Mehanny and H. A. El Howary, "Assessment of RC moment frame buildings in moderate seismic zones: Evaluation of Egyptian seismic code implications and system configuration effects," Eng. Struct., vol. 32, no. 8, pp. 2394-2406, 2010., http://dx.doi.org/10.1016/j.engstruct.2010.04.014.

[62] T. D. Ancheta et al., "NGA-West2 Database," Earthq. Spectra, vol. 30, no. 3, pp. 989-1005, 2014., http://dx.doi.org/10.1193/070913EQS197M.

[63] N. Luco and C. A. Cornell, "Structure-specific scalar intensity measures for near-source and ordinary earthquake ground motions," Earthq. Spectra, vol. 23, no. 2, pp. 357-392, 2007., http://dx.doi.org/10.1193/1.2723158.

[64] J. J. Bommer and A. B. Acevedo, "The use of real earthquake accelerograms as input to dynamic analysis," J. Earthquake Eng., vol. 8, no. sup001, pp. 43-91, 2004, https://doi.org/10.1080/13632460409350521.

Author contributions: EMVP: conceptualization, formal analysis, funding acquisition, methodology, writing-original draft; GHFC, IDR: funding acquisition, methodology, writing-review \& editing; LCMVJ, GHS: project administration, supervision, writing-review \& editing.

Editors: Sergio Hampshire C. Santos, Guilherme Aris Parsekian. 